\title{
Sodium dodecyl sulfate as a viral inactivator and future perspectives in the control of small ruminant lentiviruses
}

\section{Emprego do dodecil sulfato de sódio como inativador viral e suas perspectivas no controle de lentivírus de pequenos ruminantes}

\author{
Ana Lídia Madeira de Sousa ${ }^{1 *}$ (D), Raymundo Rizaldo Pinheiro² ${ }^{(\mathbb{D},}$, Juscilânia Furtado Araújo' (D), \\ Dalva Alana Aragão de Azevedo' (D), Renato Mesquita Peixoto ${ }^{3}$ (D), Alice Andrioli² (D), \\ Sabrina Tainah da Cruz Silva Bezerra' ${ }^{1}$, Maria Fátima da Silva Teixeira'
}

\begin{abstract}
Infections by small ruminant lentiviruses (SRLVs) affect goats and sheep causing chronic multisystemic diseases that generate great economic losses. The caprine lentivirus (CLV) and the ovine lentivirus (OLV) present tropism for cells of the monocyte/macrophage lineage, which are directly associated with the main route of transmission through the ingestion of milk and colostrum from infected animals. In this manner, controlling this route is of paramount importance. Currently, researches have investigated the use of chemical additives in milk that can preserve colostrum or milk and inactivate microbiological agents. Among the compounds, sodium dodecyl sulfate (SDS) has been shown to be satisfactory in the chemical inactivation of HIV and CLV in milk, and also as a biocide in goat colostrum.
\end{abstract}

KEYWORDS: colostrum; chemical inactivation; milk; monocyte/macrophage system.
RESUMO: As lentiviroses de pequenos ruminantes (LVPRs) são infecções que afetam caprinos e ovinos, causando doenças multissistêmicas crônicas, ocasionando grandes perdas econômicas. Os agentes causadores, lentivírus caprino (LVC) e o lentivírus ovino (LVO), apresentam tropismo por células da linhagem monocítico-fagocitária, as quais estáo diretamente associadas à principal via de transmissão, por meio da ingestáo de leite e colostro provindos de animais infectados. Desse modo, o controle por esta via é de suma importância. Atualmente, pesquisas vêm sendo desenvolvidas para o uso de aditivos químicos no leite, que possam conservar o colostro ou leite, e inativar agentes microbiológicos presentes. Dentre estes, o dodecil sulfato de sódio (SDS) vem apresentando resultados satisfatórios na inativação química do HIV e LVC em leite, e ainda como biocida em colostro caprino.

PALAVRAS-CHAVE: colostro; inativação química; leite; sistema monicítico-fagocitário. 


\section{INTRODUCTION}

The use of chemical compounds as antivirals in humans has been investigated as possible control forms of sexually transmitted diseases, especially in association with preservatives and topical microbicides (KABAMBA et al., 2016). Most of these compounds are surfactants that solubilize bacterial and viral membranes, inactivating the pathogens. Among studies, the most investigated substances are nonoxynol-9, C31G or SAVVY ${ }^{\circledast}$ (Cellegy Pharmaceuticals, Quakertown, PA, EUA), n-Lauroylsarcosine and sodiumdodecyl-sulfate (SDS) (KREBS et al., 1999; ROY et al., 2001; KABAMBA et al., 2016).

SDS is a broad-spectrum surfactant (URDANETA et al., 2005) that have presented efficient activity as a topical microbicide and viral inactivator against HIV (human immunodeficiency virus), HPV (human papillomavirus) and HSV (herpes simplex virus) (PIRET et al., 2002). Antiviral activity in human milk was also investigated in an in vitro study performed by URDANETA et al. (2005). The microbicide effect has also been evaluated in caprine colostrum, which presented effective results (MORALES-DE LA NUEZ et al., 2011). In addition, SOUSA (2016) aimed to prevent milk transmission of the caprine arthritis encephalitis virus (CAEV) with SDS acting as a prophylactic microbicide and observed a possible reduction of the viral load in milk and colostrum.

Hence, this study aimed to briefly review general characteristics and toxicity levels of SDS in addition to its potential as a viral inactivator.

\section{SODIUM DODECYL SULFATE: BIOCHEMICAL CHARACTERIZATION AND VIRAL INACTIVATION}

\section{General characteristics}

Sodium dodecyl sulfate (SDS) or sodium lauryl sulfate (SLS), chemical formula $\mathrm{NaC}_{12} \mathrm{H}_{25} \mathrm{SO}_{4}$ (IUPAC, 2014), is a tensoactive agent that has detergent properties. SDS possesses a zwitterionic form in aqueous solution with two distinct portions, polar and apolar, at opposite ends of a single molecule (Fig. 1). The polar end is formed by a sulfate group while the opposite end, apolar, is composed by a long chain hydrocarbon, which may be linear, branched or aromatic according to the diluent solution (SINGER; TJEERDEMA, 1993).

SDS chemical structure was described for the first time by Lottermoser and Stoll in Germany, 1993. Afterwards, this compound was classified as tensoactive or surfactant containing $6-18$ carbon atoms. Its use as a detergent propagated the chemistry technology in the first half of the 19th century when synthetic alternatives were developed to substitute detergents of animal origin, which were often used at the time (KIRK-OTHMER, 1984).

SDS is useful due to its chemical nature that provides adequate ionic balance, solubilizing fats and oils, and the formation of microemulsions. Hence, there are different uses for this substance, such as an ingredient in cleaning products, cosmetic production and in biological research (SINGER; TJEERDEMA, 1993). SDS has cytolytic properties, which are useful in the preparation of subcellular materials for biochemical studies, such as plasmatic membranes, organelles and genetic material. In addition, it also aided in the development of proteomics, identification of proteins and determination of structures with polyacrylamide gel electrophoresis (SDS-PAGE) (SHAPIRO et al., 1967).

\section{Cytolytic activities}

Cell membranes are characterized by an architecture containing lipid bilayers. These lipids are amphipathic with a hydrophobic and a hydrophilic end in the same molecule. These membranes are impermeable to most polar or charged solutes but are permeable to apolar compounds (NELSON; COX, 2011).

In direct contact with cells, SDS cause physical and biochemical effects. The main targeted structure is the cell membrane in every type of cell, and it is able to undo its barrier capacity (BENOIT et al., 1987; PARTEARROYO et al., 1990). The cytotoxic effects are dependent of absolute concentrations and lipid/surfactant molar ratios. When in low concentrations of surfactants, cell membranes lose their barrier capacity increasing permeability (KALMANZON et al., 1992). On the other hand, equal or superior surfactant/lipid ratios cause cell lysis (PARTEARROYO et al., 1990).

According to BARTNIK (1992), three interaction phases may be established when SDS is added in high concentrations and surfactant levels surpass those of cellular lipids. Initially, the tensoactive may cause membrane permeability alterations.

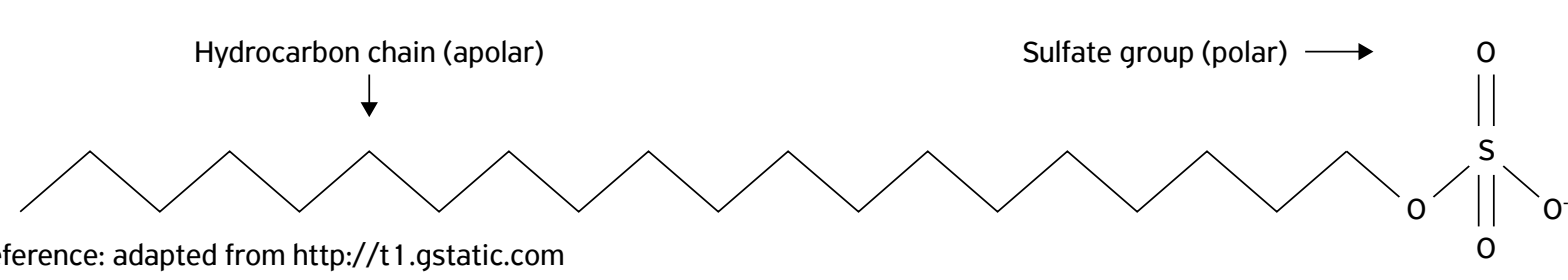

$\mathrm{Na}^{+}$

Figure 1. Chemical representation of sodium dodecyl sulfate. 
Then, if it exceeds cytolytic concentrations, the lamellar structure of the membrane is solubilized releasing proteins, lipoproteins and micelles, determining a complete cell lysis. In the third phase, phospholipid separation and structural denaturation of proteins occur. SDS is one of the ionic tensoactives that can perform covalent bonds, which usually results in conformational alterations and simultaneous loss of biological activity.

\section{Toxicity levels}

SDS toxicity is attributed to the use of high doses of the product. According to the data provided by the United Nations Environment Programme (UNEP, 1997), this substance may be considered with a low potential risk for humans and the environment. Table 1 shows toxicity levels of SDS in several species.

The estimated human exposure results reported by UNEP (1997) revealed that SDS does not present risk to the human health. According to the data, daily use of SDS in kids $(15 \mathrm{~kg})$ and in babies $(5 \mathrm{~kg}$ ) was considered safe with doses of 0.158 and $0.034 \mathrm{mg} / \mathrm{kg} / \mathrm{day}$, respectively. In addition, maximum consumption of SDS was $1 \mathrm{~g} / \mathrm{kg} /$ day for kids. This includes exposure to body lotions and oral ingestion of contaminated water or toothpaste (DREISBACH; ROBERTSON, 1987).

\section{Use as a viral inactivator}

SDS has showed potent inhibition of enveloped and nonenveloped viruses causing dissociation of the viral envelope and capsid proteins through denaturation. These proteins play different roles in the viral replication cycle from adhesion to viral encapsidation (PIRET et al., 2002).

Sexually transmitted diseases have global incidence, morbidity and mortality with significant levels. The human immunodeficiency virus type 1 (HIV-1), herpes simplex virus (HSV) and human papillomavirus (HPV) are part of these rates (BRUGHA et al., 1997). SDS mechanism of action has shown efficiency in chemically inactivating these viruses, denaturing proteins from the envelope and/or capsid in HeLa cell culture (human cells from Henrietta Lacks) (PIRET et al., 2002; KREBS et al., 1999). Furthermore, this surfactant does not compromise the vaginal mucosa of rabbits. Hence, it is a good option for use as a topical microbicide to prevent sexually transmitted pathogenic agents, which could be a high impact tool to the public health (PIRET et al., 2000, 2002).

Figure 2 demonstrates a dose-dependent effect of SDS against HSV-1 in VERO cells (African green monkey kidney cells). Low concentrations $(\leq 50 \mu \mathrm{M})$ did not reduce synthesis of viral glycoprotein $\mathrm{D}(\mathrm{gD})$. However, viral infectivity was

Table 1. Sodium dodecyl sulfate toxicity levels in different species.

\begin{tabular}{|c|c|c|c|}
\hline Species & Application & Results & Reference \\
\hline \multirow{6}{*}{ Rats } & Intraperitoneal & $\mathrm{LD}_{50}=210 \mathrm{mg} / \mathrm{kg}$ & EPSTEIN et al. (1939) \\
\hline & 5 and $10 \%$ in water for 5 days & $100 \%$ lethality & EPSTEIN et al. (1939) \\
\hline & 2 and $4 \%$ in feed for 4 months & $\begin{array}{l}\text { No reaction and growth } \\
\text { reduction, respectively. }\end{array}$ & FITZHUGH; NELSON (1948) \\
\hline & Intravenous & $\mathrm{LD}_{50}=188 \mathrm{mg} / \mathrm{kg}$ & CASCORBI et al. (1963) \\
\hline & $\begin{array}{c}\text { Acute oral } \\
\text { Repeated doses }\end{array}$ & $\mathrm{LD}_{50}{ }^{1}=1200 \mathrm{mg} / \mathrm{kg}$ & UNEP (1997) \\
\hline & (oral hepatotoxicity) & $\mathrm{NOAEL}^{2}=100 \mathrm{mg} / \mathrm{kg} / \mathrm{day}$ & UNEP (1997) \\
\hline Guinea pigs & Acute dermal & $\mathrm{LD}_{50}=>1200 \mathrm{mg} / \mathrm{kg}$ & UNEP ( 1997$)$ \\
\hline Rabbits and mouse & $\begin{array}{l}\text { Toxicity for development/ } \\
\text { teratogenicity }\end{array}$ & $\begin{array}{l}\text { NOAEL } \leq 300 \mathrm{mg} / \mathrm{kg} / \mathrm{day} \\
\text { (maternal toxicity) } \\
\text { NOAEL }=600 \mathrm{mg} / \mathrm{kg} / \mathrm{day} \\
\text { (fetal malformation) }\end{array}$ & UNEP (1997) \\
\hline Rabbits & Acute dermal toxicity & $\mathrm{LD}_{50}=600 \mathrm{mg} / \mathrm{kg}$ & UNEP (1997) \\
\hline \multirow{3}{*}{ Mouse } & Intraperitoneal & $\mathrm{LD}_{50}=250 \mathrm{mg} / \mathrm{kg}$ & GALE; SCOTT (1953) \\
\hline & Oral & $\mathrm{LD}_{50}=2700 \mathrm{mg} / \mathrm{kg}$ & GLOXHUBER (1972) \\
\hline & Reproductive route (male fertility) & NOAEL $=1000 \mathrm{mg} / \mathrm{kg} / \mathrm{day}$ & UNEP (1997) \\
\hline Dogs & Oral: $135 \mathrm{mg} / \mathrm{kg} /$ day for 10 months & No reaction & FOGELSON; SHOCH (1944) \\
\hline \multirow[t]{2}{*}{ Goat kids } & Oral: $0.5 \%$ in milk & $\begin{array}{c}\text { Apathy and light diarrhea in } 7 \\
\text { days of treatment }\end{array}$ & SOUSA (2016) \\
\hline & Oral: $1 \%$ in milk & $\begin{array}{c}\text { Apathy, severe diarrhea and } \\
\text { death in } 72 \text { hours of treatment }\end{array}$ & SOUSA (2016) \\
\hline
\end{tabular}

'average lethal concentration, ${ }^{2}$ no adverse effects were observed. 
completely inhibited, which suggests that the surfactant could interfere with the maturation of nucleocapsids and with encapsidation of nucleic acids (Fig. 2A). In contrast, viral activity in SDS concentrations higher than $100 \mu \mathrm{M}$ caused a reduction of $65.1 \%$ in $\mathrm{gD}$ synthesis. In these conditions, envelope solubilization of most of the investigated viruses was observed and the remaining particles were not able to penetrate cells and continue with the natural replication process (Fig. 2B) (PIRET et al., 2000, 2002).

URDANETA et al. (2005) demonstrated that $0.1 \%$ SDS could effectively inactivate HIV-1 in milk and the proposed treatment concentrations were within the safe limits for SDS ingestion in kids. These authors evaluated their samples in a rapid in vitro system (Multinuclear Activation of Galactosidase Indicator - MAGI) that quantifies viral infectivity after microbicide treatment. The results showed that SDS use for $10 \mathrm{~min}$ utes at 0.1 and $0.5 \%$ in HeLa cell culture was sufficient to totally inhibit viral infection caused by HIV-1 in maternal milk.

URDANETA et al. (2005) and HARTMANN et al. (2006) described SDS as an efficient microbicide in the treatment of human milk against HIV-1 with the following characteristics: efficiency in low doses, low toxicity level, broad-spectrum of microbicide activity, odorless and tasteless properties. Hence, it can be used to conserve nutritional and immune-related traits

A
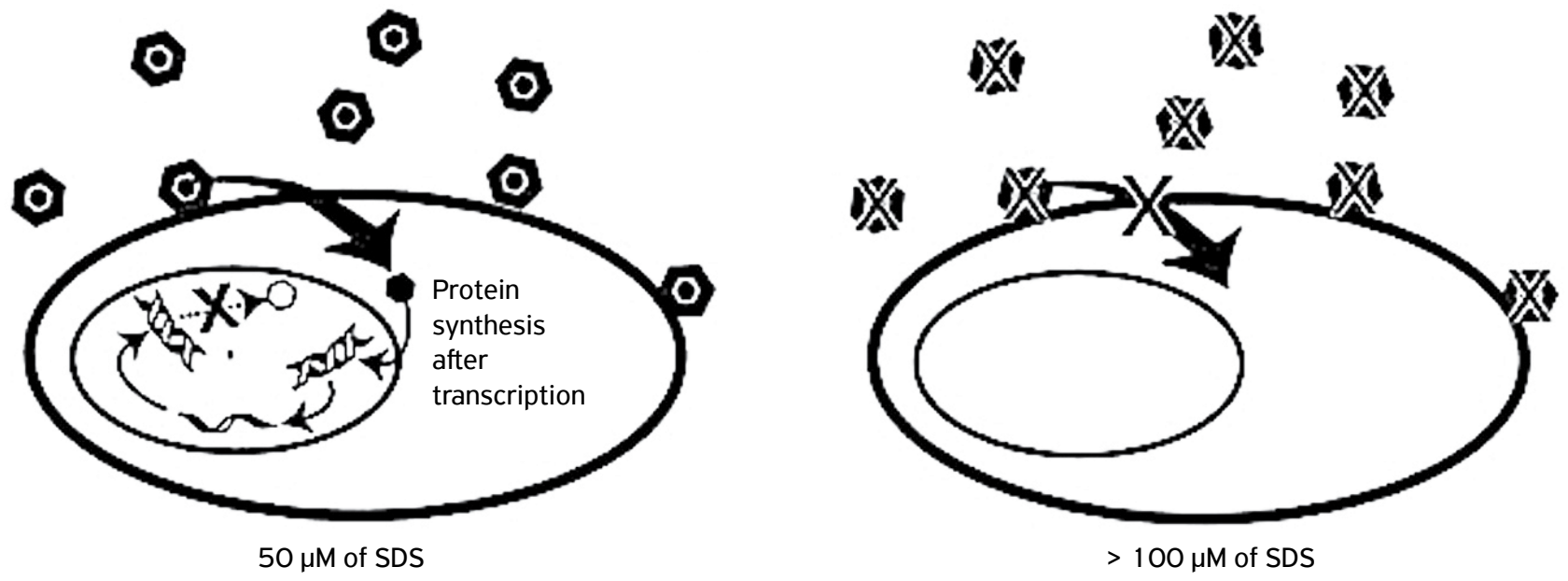

B
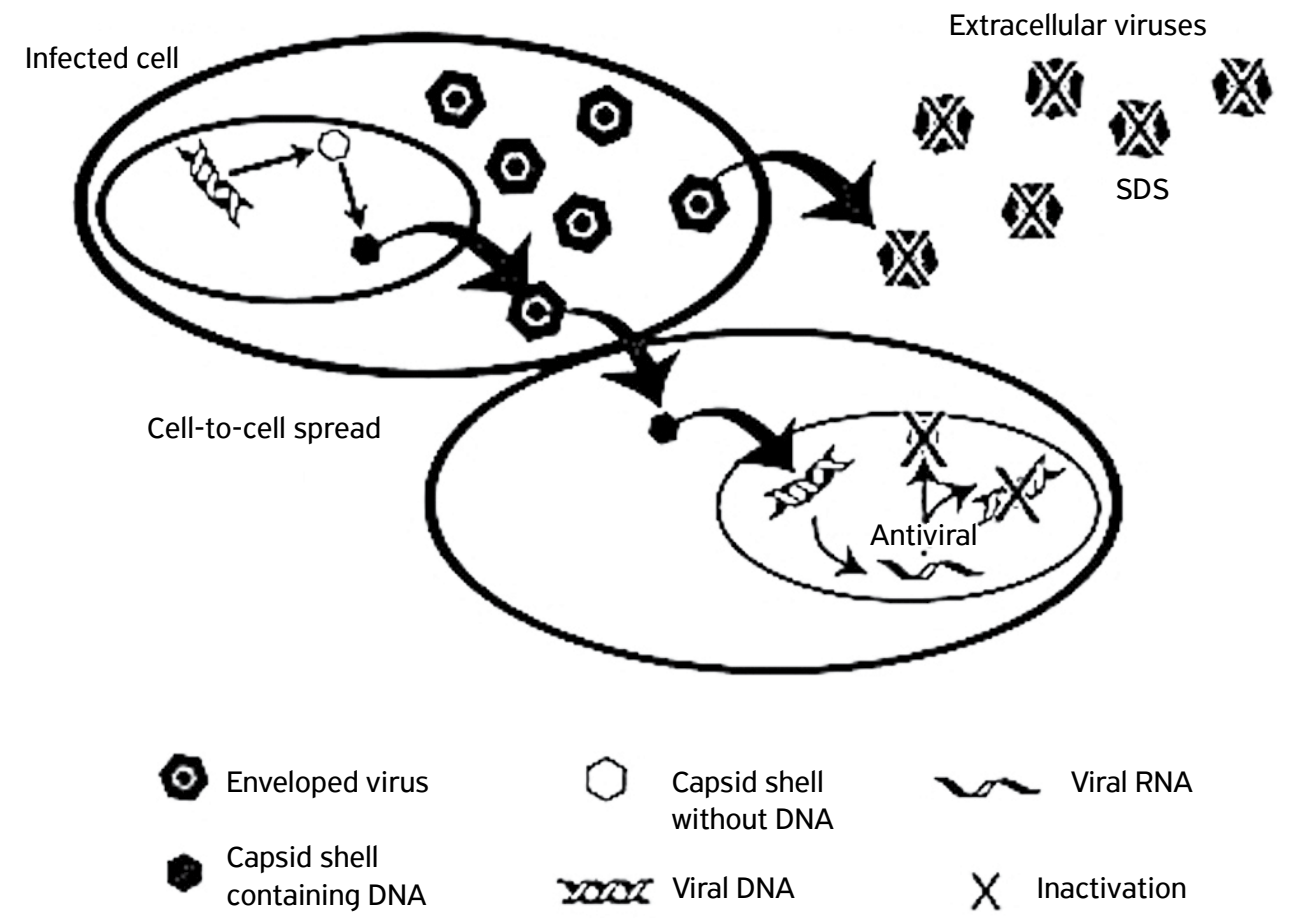

Source: PIRET et al. (2002) with modifications.

Figure 2. Dose-dependent mechanism of action of sodium dodecyl sulfate against HSV-1. 
of milk. Due to the broad-spectrum, SDS may also eliminate other pathogens from milk (secondary contaminant bacteria), which could potentially contaminate it during manipulation.

In goat production, MORALES-DE LA NUEZ et al. (2011) demonstrated that caprine colostrum treated with SDS at $1 \%$ reduced bacterial load at a rate similar to pasteurization. However, IgG destruction in SDS treated colostrum is significantly lower than pasteurized colostrum. In addition, goat kids fed with colostrum added $1 \%$ of SDS did not present pathological deficit or alterations in the transmission of passive immunity.

An in vitro study with SDS at $0.25,0.5$ and $1 \%$ in colostrum and milk performed by SOUSA (2016) revealed dosedependent effects in caprine synovial membrane cell cultures (CSM). According to the SDS concentration in treatments $(0.25$ and $0.5 \%)$, a gradual reduction of cytopathic effects occurred (CPE). On the other hand, cells with signs of viral infection were not observed in colostrum treated with $1 \%$ SDS. In milk, the absence of CPE was more relevant, which was observed in concentrations of 0.5 and $1 \%$. In addition, CLV particles were not identified in milk samples treated with $1 \%$ SDS and investigated with nested polymerase chain reaction (nPCR), which demonstrates antiviral activity against this pathogen.

The same author performed in vivo studies, in which goat kids were fed with colostrum and milk from CAE positive goat nannies and treated with SDS in the same concentrations used in the in vitro experiment. Hence, animals that received SDS in 0.25 and $0.5 \%$ presented positive results for the CLV in the early phases of monitoring. However, animals that received $1 \%$ SDS presented positive result only after 90 days of study. Probably, this dosage diminished the viral load and consequently delayed the infection but did not fully prevent it. Nonetheless, this concentration promoted gastrointestinal complications, such as profuse diarrhea.

\section{GENERAL CHARACTERISTICS OF SMALL RUMINANT LENVIRUS INFECTIONS}

Goat and sheep production are associated with traditional systems of subsistence and with economic factors, where animal production tends to be more intensive and demands more efficient production systems (GUILHERME et al., 2017). However, health management with late diagnoses of diverse diseases of different etiologies drastically interferes in the performance of these activities (AZEVEDO et al., 2017). Among the most relevant health problems are the infections caused by small ruminant lentiviruses (SRLVs). These pathogens are classified in two phylogenetic groups, the CAEV or caprine lentivirus (CLV), and the Maedi-Visna virus (MVV) or ovine lentivirus (OLV) (BLACKLAWS, 2012).

These diseases cause considerable losses in goat and sheep productions, which may compromise the profitability of the animal farm (AZEVEDO et al., 2017). In addition, the main clinical signs of both infections include arthritis, encephalitis, mastitis and, less frequently, respiratory conditions. Furthermore, animals from all ages, sex and races are susceptible (FRANKE, 1998).

SRLV have several transmission pathways, such as the lactogenic route, either through contaminated milk or colostrum (PISONI et al., 2010). The reproductive transmission may occur through the presence of the virus in the semen of infected breeders (TRAVASSOS et al., 1999; ANDRIOLI et al., 2002, 2006; SOUZA, 2013). The horizontal route may occur in direct contact between animals through feces, saliva, urogenital and respiratory secretions (RADOSTITS et al., 2002; SOUZA et al., 2015). The vertical transmission may occur via transplacental passage (RODRIGUES et al., 2017).

\section{LACTOGENIC TRANSMISSION OF SMALL RUMINANT LENTIVIRUSES}

\section{Mononuclear phagocyte system}

Monocytes and macrophages play a key role in the regulation of the immune system, guiding innate and specific immune responses (FLORES, 2007). A monocyte circulates the bloodstream until it migrates to a tissue and matures into a macrophage (TIZARD, 2014).

These cells are present in tissues, blood, colostrum and milk, among other biological fluids, which are related to the main transmission pathways of SRLV (ZINK; JOHNSON, 1994). SRLV-free flocks usually get infected through contact with carrier animals short after introduction (PISONI et al., 2010).

Pathogeny of these lentivirus infections is directly related to cells of the mononuclear phagocyte system with a focus on differentiation and maturation of monocytes into macrophages, where the viral multiplication occurs (NARAYAN et al., 1983; GENDELMAN et al., 1986). However, when in vivo, macrophages are the most infected cells (NARAYAN; CLEMENTS, 1989; LUJÁN et al., 1994; BRODIE et al., 1995). Lymphocytes may also be targeted with a less efficient viral multiplication (ZINK; JOHNSON, 1994).

\section{Milk and colostrum cells}

Colostrum is characterized as a secretion from the mammary gland produced in the last weeks of pregnancy that holds essential nutrients for the nutrition and immunological development of the newborn (HERNÁNDEZ-CASTELLANO et al., 2014; SÁNCHEZ-MACÍAS et al., 2014; TIZARD, 2014). Milk is defined as a lacteous secretion practically free of colostrum. It is composed in general by $87 \%$ of water, carbohydrates, lipids, proteins, numerous mineral salts, lactose, urea, 
lactic acid, creatinine, amino acids and water-soluble vitamins (SERTÃOBRAS, 1952; SÁNCHEZ-MACÍAS et al., 2014).

Somatic cells that compose milk and colostrum may originate from epithelium or the immune system. Epithelial cells are derived from natural peeling of the secretory epithelium of the mammary gland. Cells from the immune system, usually leukocytes (macrophages, lymphocytes and neutrophils), are those that migrate from the bloodstream to the alveoli (HERNÁNDEZ-CASTELLANO et al., 2014; SÁNCHEZMACÍAS et al., 2014; TIZARD, 2014).

\section{Lactogenic transmission via}

Lactogenic transmission is a natural model of infection that is more effective in lentiviruses. It plays a key role in SRLV biology, as in other lentiviruses, such as HIV and SIV. In fact, it is considered the main pathway of SRLV transmission in goats, since it guarantees the dissemination between generations and the persistence in flocks on a population level. Maternal leukocytes are absorbed by the intestine of newborns and enter their peripheral circulation. The great intestinal permeability in this phase favors the entry of the virus through the ingestion of contaminated colostrum (PISONI et al., 2010).

According to HERRMANN-HOESING et al. (2007), animals are exposed to infection after ingesting colostrum, either by free viruses or proviruses within monocytes/macrophages, which demonstrates efficient transmission between mother and offspring. Goat kids that are born from seronegative nannies and receive colostrum and/or milk from seropositive females soon become infected. Hence, a single ingestion of these fluids is sufficient to start the infection (RADOSTITS et al., 2002).

Furthermore, lactogenic transmission was also observed in interspecies contact as described by SOUZA et al. (2015). In this study, newborn lambs received colostrum from goat nannies positive for CAE and during the seven days of the experiment, seven out of nine $(77.78 \%)$ of the group were positive for the virus in $\mathrm{nPCR}$.

\section{METHODS FOR BLOCKING THE LACTOGENIC TRANSMISSION}

Several prophylactic measures for SRLV have been suggested in studies throughout the years (ROWE et al. 1992; PERETZ, et al., 1993; ALVES, 1999; NOGUEIRA et al., 2009). Among these, the control of the lactogenic pathway is critical due to its potential of transmission from breeders to their offspring (ROWE et al., 1992; PERETZ et al., 1993; RADOSTITS et al., 2002; PISONI et al., 2010; SOUZA et al., 2015). The most used techniques by farmers are:

- Use of artificial colostrum: this is composed by $700 \mathrm{~mL}$ of bovine milk (healthy and specifically free of bovine viral diarrhea - BVD), $300 \mathrm{~mL}$ of blood serum from negative goats or sheep, and one chicken egg (ALVES, 1999). The serum is obtained through blood collection without anticoagulant following centrifugation.

- Use of bovine colostrum: colostrum from cows is also recommended to feed goats and sheep. However, donors for this purpose must be healthy, especially concerning bovine leukosis to prevent interspecies transmission (PERETZ et al., 1993; NOGUEIRA et al., 2009).

- Thermal treatment of colostrum and milk: thermization procedure may be performed in colostrum, transition milk and common milk. For example, colostrum is collected in plastic bottles from females after delivering, which are sealed and heated at $56^{\circ} \mathrm{C}$ in water bath for one hour. Then, bottles are removed and cooled naturally to room temperature before being stocked at $-15^{\circ} \mathrm{C}$ (PERETZ, et al., 1993; ANDRADE, 2008; NOGUEIRA et al., 2009).

- Milk pasteurization: milk may be conserved through pasteurization, which is a method that maintains organoleptic and nutritional characteristics and ensures destruction of pathogenic micro-organisms guaranteeing a healthy food (CHEFTEL et al., 1989; RIEDEL, 1996). There are two types of pasteurization, which are slow and fast. In slow pasteurization, milk is heated to 63 to $65^{\circ} \mathrm{C}$ for $30 \mathrm{~min}$ utes and cooled to $4^{\circ} \mathrm{C}$. During the heating period, milk is moderately agitated to avoid adhesion to the walls of the bottle, to promote uniform heating of all particles and in the same time to avoid foam formation (PRATA, 2001; LEITE et al., 2006). Fast pasteurization of the High Temperature Short Time (HTST) method consists of heating the milk to 72 to $75^{\circ} \mathrm{C}$ for 15 to 20 seconds following immediate cooling to $5^{\circ} \mathrm{C}$, which causes a thermal shock (LEITE et al., 2006).

However, these methods may be considered costly due to the need for trained laborers and equipment, such as water baths or thermizators, and centrifuges. Hence, the search for practical and low-cost alternatives that are efficient in blocking SRLV transmission in colostrum and milk are necessary for farmers to control the dissemination of these diseases in flocks.

\section{CONCLUSION}

This study demonstrated the antiviral potential of SDS in the prevention of sexually transmitted diseases and in SRLV prophylaxis. In addition, general aspects of the lactogenic transmission of CLV, advantages of SDS use as a viral inactivator in human research and promising results of its application as a chemical inactivator of CLV were presented. Although several studies have reported the antiviral activity of SDS, there is still a lack of data that can assess its effects on SRLV and the application as a control measure for the lactogenic transmission. 


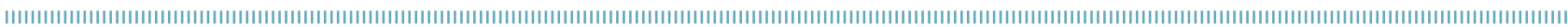
REFERENCES

ALVES, F.S.F. Artrite encefalite caprina a vírus: prevenção e controle. Sobral: Embrapa Caprinos, 1999. 11 p. (Circular Técnica, 15).

ANDRADE, M.L.R. Avaliação da dinâmica de absorção do colostro em caprinos das raças saanen e moxotó explorados no semi-árido cearense. 2008. 60f. Dissertation (Master's degree in Zootechnics) - Universidade Estadual Vale do Acaraú, Sobral, 2008.

ANDRIOLI, A.; GOUVEIA, A.M.G.; MOURA SOBRINHO, P.A.; PINHEIRO, R.R.; SALLES, H.O. Transferência de embriões em cabras naturalmente infectadas pelo lentivírus caprino. Revista Brasileira de Medicina Veterinária, v.24, n. 1, p.215-220, 2002.

ANDRIOLI, A.; GOUVEIA, A.M.G.; MARTINS, A.S.; PINHEIRO, R.R.; SILVA, D.O. Fatores de risco na transmissão do lentivírus caprino pelo sêmen. Pesquisa Agropecuária Brasileira, v.41, n.8, p.1313-1319, 2006. http://dx.doi.org/10.1590/S0100-204X2006000800015

AZEVEDO, D.; SANTOS, V.S.; SOUSA, A.; PEIXOTO, R.; PINHEIRO, R.R.; ANDRIOLI, A.; TEIXEIRA, M.F. Small ruminant lentiviruses: economic and productive losses, consequences of the disease. Arquivos do Instituto Biológico, v. 84, n.1, p.1-10, 2017. http:// dx.doi.org/10.1590/1808-1657000552016

BARTNIK, F.G. Interaction of anionic surfactants with proteins, enzymes, and membranes. In GLOXHUBER, C.H.; KIINSTLER, K. (Eds.). Anionic surfactants: biochemistry, toxicology, dermatology. 2. ed. Marcel Dekker: New York, 1992. p.1-42.

BENOIT, J.; CORMIER, M.; WEPIERRE, J. Effect of proteins on the assessment of surfactant cytotoxicity by an in vitro test: Possible correlation with in vivo data. Toxicology in Vitro, v. 1, n.2, p.91-96, 1987. https://doi.org/10.1016/0887-2333(87)90006-3

BLACKLAWS, B.A. Small ruminant lentiviruses: Immunopathogenesis of visna- maedi and caprine arthritis and encephalitis virus. Comparative Immunology, Microbiology and Infectious Diseases, v.35, n.1, p.259-269, 2012.https://doi.org/10.1016/j.cimid.2011.12.003

BRODIE, S.; PEARSON, L.; ZINK, M.C.; BICKLE, H.M.; ANDERSON, B.C.; MARCOM, K.A.; DEMARTINI, J.C. Ovine lentivirus expression and disease. Virus replication, but not entry, is restricted to macrophages of specific tissues. American Journal of Pathology, v.146, n.1, p.250-263, 1995.

BRUGHA, R.K.; KEERSMAEKERS, A.; RENTON, E.A. Genital herpes infection: a review. International Journal of Epidemiology, v.26, n.4, p.698-709, 1997. https://doi.org/10.1093/ije/26.4.698

CASCORBI, H.F.; RUDO, F.G.; LU, G.G. Acute toxicity of intravenous sodium lauryl sulfate. Journal of Pharmacological Sciences, v.52, n.8, p.803-805, 1963. https://doi.org/10.1002/jps.2600520822

CHEFTEL, J.C.; CHEFTEL, H.; BESANÇON, P. Métodos de conservación - calor. In: Introducción a la bioquimica y tecnologia de los alimentos. v.2. Zaragoza: Acríbia, 1989, p.236-271.
DREISBACH, R.H.; ROBERTSON, W.O. Miscellaneous Chemicals. In Handbook of poisoning: Prevention, diagnosis \& treatment. 12. ed. Norwalk: Appleton \& Lange, 1987. p.286-291.

EPSTEIN, S.; THRONDSON, W.D.; TAINTER, M.L. Possible deleterious effects of using soap substitutes in dentifrices. The Journal of the American Dental Association, v.26, n.1, p.1461-1471, 1939.

FITZHUGH, O.G.; NELSON, A.A. Chronic oral toxicities of surfaceactive agents. Journal of the American Pharmacists Association, v.37, n. 1, p.29-32, 1948.

FLORES, E.F. Virologia Veterinária. Santa Maria: Ed. da UFSM, 2007. p.67.

FOGELSON, S.J.; SHOCH, D.E. Treatment of gastroduodenal ulcerative disease with sodium alkyl sulfate. Archives of Internal Medicine, v.73, n.3, p.212-216, 1944. https://doi.org/10.1001/ archinte. 1944.00210150015003

FRANKE, C.R. Controle sanitário da artrite-encefalite caprina. Salvador: EDUFBA, 1998. p.70.

GALE, L.E.; SCOTT, P.M. A pharmacological study of a homologous series of sodium alkyl sulfates. Journal of the American Pharmacists Association. v.42, n.5, p.283-287, 1953.

GENDELMAN, H.E.; NARAYAN, O.; KENNEDY-STOSKPF, S.; KENNEDY, P.G.E.; GHOTBI, Z.; CLEMENTS, J.E.; STANLEY, J.; PEZESHKPOUR, G. Tropism of sheep lentivirus for monocytes: susceptibility to infection and virus gene expression increase during maturation of monocytes to macrophages. Journal of Virology, 58.1, n.1, p.67-74, 1986.

GLOXHUBER, C.H. Toxicology of basic materials in washing and cleaning agents. Fette, Seifen, Anstrichmittel, v.74, n. 1, p.49-57, 1972. https://doi.org/10.1002/lipi.19720740110

GUILHERME, R.F; LIMA, A.M.C.; ALVES, J.R.A; COSTA, D.F.; PINHEIRO. R.R.; ALVES, F.S.F.; AZEVEDO, S.S.; ALVES, C.J. Characterization and typology of sheep and goat production systems in the State of Paraíba, a semi-arid region of northeastern Brazil. Semina: Ciências Agrárias, v.38, n.4, p.2163-2178, 2017. http://dx.doi.org/10.5433/1679-0359.2017v38n4p2 163

HARTMANN, S.U.; WIGDAHL, B.; NEELY, E.B.; BERLIN, C.M.; SCHENGRUND, C.L.; LIN, H.M.; HOWETT, M.K. Biochemical analysis of human milk treated with sodium dodecyl sulfate, an alkyl sulfate microbicide that inactivates human immunodeficiency virus type 1. Journal of Human Lactation, v.22, n. 1, p.61-74, 2006. https:// doi.org/10.1177/0890334405280651

HERNÁNDEZ-CASTELLANO, L.E.; ALMEIDA, A.M.; CASTRO, N.; ARGÜELLO, A. The colostrum proteome, ruminant nutrition and immunity: a review. Current Protein $\odot$ Peptide Science, v. 15, n. 1 , p.64-74, 2014. https://doi.org/10.2174/1389203715666 140221124622 
HERRMANN-HOESING, L.M.; PALMER, G.H.; KNOWLES, D.P. Evidence of proviral clearance following postpartum transmission of an ovine lentivirus. Virology, v.362, n. 1, p.226-234, 2007. https://doi.org/10.1016/j.virol.2006.12.021

INTERNATIONAL UNION OF PURE AND APPLIED CHEMISTRY (IUPAC). The IUPAC Network. 2014. Available from: http://www. acdlabs.com/iupac/nomenclature/. Access on: Nov. 272014.

KABAMBA, B.; ALEXANDREA H.T.; MUFHANDUA, G.M.; LONDONB E.; CHAKAUYAA, M.K. Progress and Perspectives on HIV-1 microbicide development. Virology, v.497, n. 1, p.69-80, 2016.

KALMANZON, E.; ZLOTKIN, E., COHEN, R.; BARENHOLZ, Y. Liposomes as a model for the study of the mechanism of fish toxicity of sodium dodecyl sulfate in sea water. Biochimica et Biophysica Acta, v.1 103, n.1, p.148-156, 1992. https://doi. org/10.1016/0005-2736(92)90068-W

KIRK-OTHMER. Encyclopedia of chemical technology. 3.ed. New York: John Wiley and Sons, 1984.

KREBS, F.C.; MILLER, S.R.; MALAMUD, D.; HOWETT, M.K.; WIGDAHL, $B$. Inactivation of human immunodeficiency virus type 1 by nonoxynol-9, C31G, or an alkyl sulfate, sodium dodecyl sulfate. Antiviral Research, v.43, n.3, p.157-173, 1999. https://doi. org/10.1016/s0166-3542(99)00044-3

LEITE, Z.T.C.; VAITSMAN, D.S.; DUTRA, P.B.; GUEDES, A. Leite e alguns de seus derivados - da antiguidade à atualidade. Química Nova, São Paulo, v.29, n.4, p.876-880, 2006. http://dx.doi. org/10.1590/SO100-40422006000400043

LUJÁN, L.; BEGARA, I.; COLLIE, D.; WATT, N.J. Ovine lentivirus (Maedi-Visna virus) protein expression in sheep alveolar macrophages. Veterinary Pathology, v.31, n.6, p.695-703, 1994. https://doi.org/10.1177/030098589403100610

MORALES-DE LA NUEZ, A.; MORENO-INDIAS, I.; SNCHEZMACÍAS, D.; CAPOTE, J.; JUSTE, M.C.; CASTRO, N.; HERNÁNDEZCASTELLANO, L.E.; ARGÜELLO, A. Sodium dodecyl sulfate reduces bacterial contamination in goat colostrum without negative effects on immune passive transfer in goat kids. Journal of Dairy Science, v.94, n. 1, p.410-415, 2011 . https://doi.org/10.3168/ jds.2010-3624

NARAYAN, O.; KENNEDY-STOSKOPF, S.; SHEFFER, D.; GRIFFIN, D.E.; CLEMENTS, J.E. Activation of caprine arthritis-encephalitis virus expression during maturation of monocytes to macrophages. Infection and Immunity, v.41, n. 1, p.67-73, 1983.

NARAYAN, O.; CLEMENTS, J.E. Biology and pathogenesis of lentiviruses. Journal of General Virology, v.70, n.7, p.1617-1639, 1989. https://doi.org/10.1099/0022-1317-70-7-1617

NELSON, D.L.; COX, M.M. Princípios de Bioquímica de Lehninger. 5. ed. Porto Alegre: Artmed, 2011.

NOGUEIRA, D.M.; PINHEIRO, R.R.; ALVES, F.S.F. Artrite encefalite caprina viral: um alerta aos produtores. Petrolina: Embrapa Semiárido, 2009. 4p. (Comunicado Técnico, 139).
PARTEARROYO, M.A.; OSTOLAZA, H.; GONI, F.M.; BARBERÁGUILLEM, E. Surfactant-induced cell toxicity and cell lysis. Biochemical Pharmacology, v.40, n.6, p.1323-1328, 1990. https://doi.org/10.1016/0006-2952(90)90399-6

PERETZ, G.; ASSO, J.; DEVILLECHAISE, P. Le CAEV: Revue des connaissances actuelles et conséquences pratiques. Revue de Médecine Vétérinaire, v.144, n.2, p.93-98, 1993.

PIRET, J.; LAMONTAGNE, J.; BESTMAN-SMITH, J.; ROY, S.; GOURDE, P.; DÉSORMEAUX, A.; OMAR, R.F.; JUHÁSZ, J.; BERGERON, M.G. In vitro and in vivo evaluations of sodium lauryl sulfate and dextran sulfate as microbicides against herpes simplex and human immunodeficiency viruses. Journal of Clinical Microbiology, v.38, n. 1, p.1 10-1 19, 2000.

PIRET, J.; DÉSORMEAUX A.; BERGERON, M.G. Sodium lauryl sulfate, a microbicide effective against enveloped and nonenveloped viruses. Current Drug Targets, v.3, n. 1, p.17-30, 2002. https:// doi.org/10.2174/1389450023348037

PISONI, G.; BERTONI, G.; MANAROШA, G.; VOGT, H. R.; SCACCABAROZZI, L.; LOCATELLI C.; MORONI, P. Genetic analysis of small ruminant lentiviruses following lactogenic transmission. Virology, v.407, n.1, p. 91-99, 2010. https://doi.org/10.1016/j.virol.2010.08.004

PRATA, L.F. Fundamentos de ciência do leite. São Paulo: Unesp, 2001. p.287.

RADOSTITS, O.M.; GAY, C.C.; BLOOD, D.C.; HINCHCLIFF, K.W. Clínica veterinária: um tratado de doenças dos bovinos, ovinos, suínos, caprinos e equinos. Rio de Janeiro: Guanabara Koogan, 2002. p.1098-1101.

RIEDEL, G. Controle sanitário do alimento. 2. ed. São Paulo: Atheneu, 1996. p.230.

RODRIGUES, A.S.; PINHEIRO, R.R.; BRITO, R.L.L.; OLIVEIRA, L.S.; OLIVEIRA, E.L.; SANTOS, V.W.S.; ANDRIOLI, A.; SOUZA, T.S.; DIAS, R.P.; TEIXEIRA, M.F.S. Evaluation of caprine arthritisencephalitis virus transmission in newborn goat kids. Arquivos do Instituto Biológico, v.84, n.1, p.1-5, 2017. http://dx.doi. org/10.1590/1808-1657000542016

ROWE, J.D.; EAST, N.E.; THURMOND, M.C.; FRANTI, C.E.; PEDERSEN, N.C. Cohort study of natural transmission and two methods for control of caprine arthritis encephalitis virus infection in goats on a California dairy. American Journal of Veterinary Research, v.53, n.12, p.2386-2395, 1992.

ROY, S.; GOURDE, P.; PIRET, J.; DÉSORMEAUX, A.; LAMONTAGNE, J.; HAINEAULT, C.; OMAR, R.F.; BERGERON, M.G. Thermoreversible Gel Formulations Containing Sodium Lauryl Sulfate or $\mathrm{n}$-Lauroylsarcosine as Potential Topical Microbicides against Sexually Transmitted Diseases. Antimicrobial Agents and Chemotherapy, v.45, n.6, p.1671-1681, 2001. https://doi. org/10.1128/AAC.45.6.1671-1681.2001

SÁNCHEZ-MACÍAS, D.; MORENO-INDIAS, I.; CASTRO, N.; MORALES-DE LA NUEZ, A.; ARGÜELLO, A. From goat colostrum to milk: physical, chemical, and immune evolution from partum to 90 days postpartum. Journal of Dairy Science, v.97, n. 1, p.10-16, 2014. https://doi.org/10.3168/jds.2013-6811 
SERTÃOBRAS. REGULAMENTO DA INSPEÇÃO INDUSTRIAL E SANITÁRIA DE PRODUTOS DE ORIGEM ANIMAL. Título VIII Inspeção Industrial e Sanitária do Leite e Derivados, Capítulo I - Leite em Natureza. 1952. p.78-92. Available from: https:// www.sertaobras.org.br/wp-content/uploads/2010/11/RIISPOA. pdf. Access on: Mar. 152018.

SHAPIRO, A.L.; VIÑUELA, E.; MAIZEL, J.V. Molecular weight estimation of polypeptide chains by electrophoresis in SDSpolyacrylamide gels. Biochemical and Biophysical Research Communications, v.28, n.5, p.815-820, 1967. https://doi. org/10.1016/0006-291x(67)90391-9

SINGER, M.M.; TJEERDEMA, R.S. Fate and effects of the surfactant sodium dodecyl sulfate. Reviews of Environmental Contamination and Toxicology, v.133, n.1, p.95-149, 1993.

SOUSA, A.L.M. Utilização do dodecil sulfato de sódio(SDS) no leite e colostro como inativador químico do vírus da Artrite Encefalite Caprina. 2016. 96f. Dissertation (Master's degree in Zootechnics) - Universidade Estadual Vale Do Acaraú, Sobral, 2016.

SOUZA, K.C.; PINHEIRO, R.R; SANTOS, D.O.; BRITO, R.L.L.; RODRIGUES, A.S.; SIDER, L.H.; PAULA, N.R.O.; AVILA, A.A.; CARDOSO, J.F.S.; ANDRIOLI, A. Transmission of the caprine arthritis-encephalitis virus through artificial insemination. Small Ruminant Research, v.109, n.2-3, p.193-198, 2013. https://doi.org/10.1016/j.smallrumres.2012.07.031

SOUZA, T.S.; PINHEIRO R.R.; COSTA, J.N.; LIMA, C.C.V; ANDRIOLI, A.; AZEVEDO, D.A.A, SANTOS, V.W.S.; ARAÚJO,
J.F.; SOUSA, A.L.M.; PINHEIRO, D.N.S; FERNANDES, F.M.C.; COSTA NETO, A.O. Interspecific transmission of small ruminant lentiviruses from goats to sheep. Brazilian Journal of Microbiology, v.46, n.3, p.867-874, 2015. http://dx.doi. org/10.1590/S1517-838246320140402

TIZARD, I.R. Imunologia Veterinária. 9. ed. Amsterdam: Elsevier, 2014.

TRAVASSOS, C.; BENOÎT, C.; VALAS, S.; SILVA, A.G.; PERRIN, G. Caprine Arthritis-Encephalitis Virus in semen of naturally infected bucks. Small Ruminant Research, v.32, n.2, p.101-106, 1999. https://doi.org/10.1016/ S0921-4488(98)00172-2

UNITED NATIONS ENVIRONMENT PROGRAMME (UNEP). SIDS initial assessment report. Sodium dodecyl sulfate (CAS No. 151- 21 -3). In Screening Information Data Sheet (SIDS) for High Volume Chemicals. v.4. Pt. 2. Geneva: UNEP/OECD/UN/ IRPTC, 1997. p.1-39.

URDANETA, S.; WIGDAHL, B.; NEELY, E.B.; BERLIN, C.M., JR.; SCHENGRUND, C.L.; LIN, H.M.; HOWETT, M.K. Inactivation of HIV-1 in breast milk by treatment with the alkyl sulfate microbicide sodium dodecyl sulfate (SDS). Retrovirology, v. 2, n.1, p.28, 2005. https://doi. org/10.1186/1742-4690-2-28

ZINK, M.C.; JOHNSON, L.K. Pathobiology of lentivirus infections of sheep and goats. Virus Research, v.32, n.2, p.139-154, 1994. https://doi.org/10.1016/0168-1702(94)90039-6 